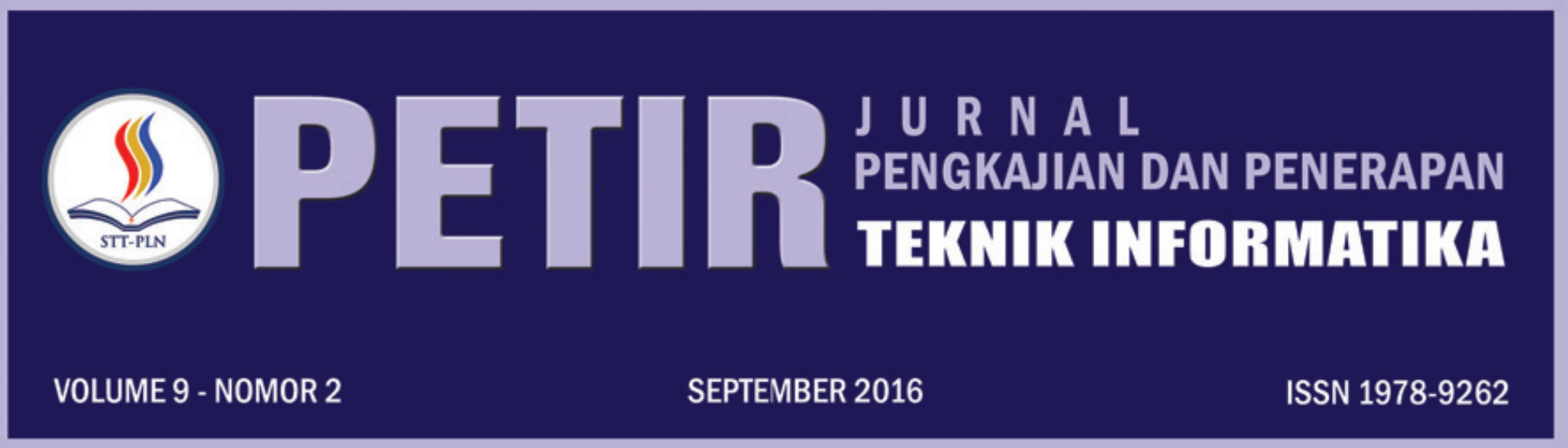

ANALISA SPASIAL UNTUK MELIHAT TINGKAT KESEJAHTERAAN MASYARAKAT DI PROVINSI BANTEN Muhamad Jafar Elly; Reza Pahlevi

PENENTUAN WILAYAH RAWAN PENYAKIT BERBASIS LINGKUNGAN DI JAKARTA TIMUR MENGGUNAKAN SISTEM INFORMASI GEOGRAFIS

Atiqah Meutia Hilda; Muhamad Jafar Elly; Windu Nugroho Cahyo Pamungkas

APLIKASI PENCARIAN USTADZ UNTUK WILAYAH DKI JAKARTA MENGGUNAKAN ALGORITMA HAVERSINE FORMULA BERBASIS ANDROID

Harni Kusniyati; Haries Fadhillah

PERENCANAAN ARSITEKTUR ENTERPRISE PERGURUAN TINGGI DENGAN PENDEKATAAN ENTERPRISE ARCHITECTURE PLANNING (EAP) (STUDI KASUS POLITEKNIK PIKSI GANESHA)

M. Farid Rifai

PERANCANGAN E-KATALOG PADA PERPUSTAKAAN DIGITAL STT-PLN BERBASIS WEB

Yessy Fitriani; Yasni Djamain; Risalatulina Dwi Kurniati

APLIKASI SISTEM GPS KEGIATAN OPERASIONAL PERSAMPAHAN DINAS PENGELOLAAN SAMPAH, PERTAMANAN DAN PEMAKAMAN (DP4) KOTA SUKABUMI

Yasmi Afrizal; Julian Chandra W
PERANCANGAN APLIKASI PENGOLAHAN DATA KAS BERBASIS ONLINE
(STUDI KASUS : KEMENTRIAN ' $X$ ')
Dian Hartanti; Lingga Desyanita

PERANCANGAN SISTEM INFORMASI PESERTA SERTIFIKASI

(Studi kasus LSP Piksi Ganesha)

Hendra Jatnika

RANCANG BANGUN APLIKASI SEC-WAY GUNA PENGINGAT BEPERGIAN DILENGKAPI INFO CUACA DAN CCTV JALAN RAYA LOKASI PILIHAN BERBASIS ANDROID STUDI KASUS DKI JAKARTA

Yasni Djamain; Intan Ratna Sari Yanti; Hari Wibowo

PREDIKSI PENERIMAAN SISWA BARU PADA MADRASAH ALIYAH AS-SAYAFI'IYAH 02 MENGGUNAKAN METODE TIME SERIES

Sarwo; Hermawan

PERANCANGAN SIMULASI MEDIA PEMBELAJARAN DENGAN METODE DIVISION REMAINDER UNTUK PENCARIAN ALAMAT RELATIF PADA PROSES PENEMPATAN DATA

Dewi Arianti Wulandari; Darma Rusjdi

ANALISIS SISTEM PENENTUAN LOKASI GANGGUAN JARINGAN DISTRIBUSI LISTRIK TERINTEGRASI GOOGLE MAP Abdul Haris; Herman Bedi Agtriadi

\begin{tabular}{|c|c|c|c|c|c|c|}
\hline \multirow{2}{*}{$\begin{array}{c}\text { ISSN } \\
|||||||||||||||||||||||||| \mid\end{array}$} & \multicolumn{6}{|c|}{ SEKOLAH TINGGI TEKNIK - PLN (STT-PLN) } \\
\hline & PETIR & VOL. 9 & NO. 2 & HAL. $89-166$ & JAKARTA, SEPTEMBER 2016 & ISSN 1978-9262 \\
\hline
\end{tabular}




\title{
APLIKASI PENCARIAN USTADZ UNTUK WILAYAH DKI JAKARTA MENGGUNAKAN ALGORITMA HAVERSINE FORMULA BERBASIS ANDROID
}

\author{
Harni Kusniyati ${ }^{1}$, Haries Fadhillah ${ }^{2}$ \\ Program Studi Informatika, Fakultas IImu Komputer, Universitas Mercu Buana \\ Jl. Raya Meruya Selatan, Kembangan, Jakarta 11650 \\ E-mail : harni.kusniyati@mercubuana.ac.id ${ }^{1}$, hariesfadhillah23@gmail.com²
}

\begin{abstract}
Abstrak
IImu agama sangatlah penting bagi kehidupan seseorang, dan bermsyarakat. Seseorang jika ingin menuntut ilmu harus datang kerumah para guru atau ke majelis-majelis ilmu disekitar rumah atau pun jarak yang agak jauh dari rumah, bahkan tidak sedikit orang yang susah mencari majelis ilmu atau guru untuk menuntut agama Islam, itu akan merugikan seseorang. Kemalasan akan datang jika seseorang sudah jenuh untuk mencari guru untuk belajar agama islam karena sulitnya mencari guru disekitar rumah.

Aplikasi Pencarian Ustadz Wilayah DKI Jakarta dan sekitarnya berbasis Android yang beralgoritma Haversine Formula. Dimaksudkan untuk mengurangi beberapa kesulitan-kesulitan dan kendala yang ada pada kehidupan seseorang demi mencari guru agama untuk belajar agama Islam khususnya. Diharapkan sistem ini dapat membantu, sistem ini dirancang dengan metode UML, untuk memudahkan penulis dalam perancangan sistem. Aplikasi ini dibangun dengan pemrograman PHP dan menggunakan basisdata MySQL. Hasil dari implementasi aplikasi yang sudah dibuat ini adalah aplikasi pencarian ustadz yang bisa digunakan dalam kehidupan bermasyarakat. Membantu proses pencarian rumah, kontak ustadz atau guru dengan cara yang efisien.
\end{abstract}

Kata Kunci : aplikasi, web, searching ustadz, haversine formula, android

\section{PENDAHULUAN}

\section{Latar Belakang}

Perkembangan teknologi saat ini memang sudah berjalan dengan cepat. Hal tersebut menjadikan kegiatan manusia untuk mengolah data dalam jumlah sedikit maupun banyak menjadi lebih cepat dan efisien. Data atau informasi yang berupa teks, audio, dan video. Di kehidupan masyarakat pun sangat penting teknologi yang mumpuni, dimulai komputer bahkan gadget yang sekarang kualitas yang sangat bagus. Sehingga dengan gadget masyarakat bisa melakukan aktifitas dengan efisien atau mudah.

Dengan berkembangnya teknologi di dunia umumnya dan khususnya di Indonesia, kita sebagai umat manusia harus tetap mempelajari ilmu agama. Ilmu agama sangatlah penting untuk masa depan yang lebih baik. Di era teknologi yang sangat canggih ini masyarakat lupa dengan belajar agama (Islam), sering mengoperasikan gadgetnya sampai lupa dengan Allah SWT karena terlalu lama mengoperasikan gadgetnya. Banyak orang yang berhalangan untuk bisa hadir di majelis-majelis ilmu agama dikarenakan kesibukan pekerjaan yang sangat padat. Para pelajar yang waktu pengajian berbarengan dengan kegiatan disekolah atau instansi dan ada pula beberapa masyarakat yang tidak tahu dimana harus mencari guru untuk belajar mengaji atau memanggil guru untuk mengisi tausyiah di tempat acaranya.

\section{Rumusan Masalah}

Berdasaran latar belakang tersebut dapat dirumuskan bahwa pemasalahan yang ada adalah :
1. Bagaimana mengimplementasikan sebuah aplikasi yang berjalan pada sistem operasi berbasis android?

2. Bagaimana mengimplementasikan aplikasi pencarian lokasi rumah ustadz/ustadzah dengan memanfaatkan memanfaatkan Global Positioning System (GPS) dan Google Map API?

3. Bagaimana menerapkan metode haversine formula dalam menentukan jarak terdekat pada aplikasi?

4. Bagaimana menerapkan radius dalam menampilkan jarak terdekat pada aplikasi?

\subsection{Batasan Masalah}

Berdasarkan perumusan masalah yang telah disebutkan diatas, maka batasan masalah pada aplikasi ini adalah sebagai berikut:

1. Aplikasi yang akan dibuat yaitu berbasis android

2. Aplikasi ini mencari lokasi rumah ustadz (navigasi), bioadata dan no telepon

3. Aplikasi ini menggunakan algoritma HAVERSINE FORMULA

Pencarian hanya wilayah DKI Jakarta

\subsection{Tujuan Penulisan}

Tujuan dari tugas akhir ini adalah Menerapkan metode Haversine formula pada aplikasi pencarian lokasi rumah ustadz/ustadzah dan menghasilkan aplikasi pencarian lokasi rumah ustadz/ustadzah berbasis android.

Adapun manfaat dari pembuatan aplikasi tersebut adalah : 
1. Menghasilkan aplikasi yang mempunyai fungsi minimal menampilkan posisi secara geografis keberadaan perangkat mobile tersebut

2. Menampilkan lokasi pencucian kendaran terdekat berdasarkan posisi pengguna serta menampilkan informasi rute menuju lokasi rumah ustadz/ustadzah.

\subsection{Metodologi}

Pada penulisan tugas akhir ini di perlukan data-data yang lengkap sebagai bahan yang dapat mendukung kebeneran materi uraian dan pembahasan. Oleh karena itu diperlukan metodologi pengumpulan data dan metode pengembanga aplikasi.

\subsubsection{Pengumpulan Data}

Pada tahap pengumpulan data, metode yang pakai adalah sebagai berikut:

\section{Metode Observasi}

Melakukan observasi untuk memperoleh datadata yang diperlukan sesuai dengan masalah yang diteliti untuk pembuatan aplikasi pencarian tokoh agama.

2. Metode Studi Pustaka (Library Research)

Mempelajari teori-teori dari buku yang berhubungan dengan perancangan aplikasi yang akan dibuat sebagai landasan dasar untuk terciptanya aplikasi pencarian tokoh agama.

\subsubsection{Metode Pengembangan Sistem.}

Pengembangan aplikasi dalam penelitian ini dilakukan menggunakan enam tahap siklus pengembangan model air terjun atau waterfall yaitu

\section{a. Tahapan Analisis}

Pada tahap ini dilakukan pengumpulan kebuthan elemen-elemen ditingkat perangkat lunak.

b. Tahapan Perancangan

Pada tahap perancangan, kebutuhankebutuhan perangkat lunak yang dihasilan pada tahap analisis, ditransformasikan kedalam bentuk arsitektur perangkat lunak yang memiliki karakteristik mudah di mengerti dan tidak sulit di terapkan.

c. Tahapan Pemrograman

Tahapan ini melakukan penerapan hasil rancangan kedalam baris-baris kode program yang dapat di mengerti computer maupun hardware.

d. Tahapan Pengujian

Setelah perangkat lunak selesai diterapkan, pengujian dapat segera dimulai. Pengujian terlebih dahulu dilakukan pada setiap modul. Jika tidak ada masalah, modul tersebut akan diintergasikan hingga membentuk perangkat lunak secara utuh.

e. Tahapan Pengoprasian dan pemeliharaan Dalam masa oprasional sehari-hari, suatu perangkat lunak mungkin saja mengalamin kesalahan atau kegagalan dalam menjalankan fungsi-fungsi. Atau, pemilik bisa saja meminta peningkat kemampuan perangkat lunak pada pengembangannya.

\section{LANDASAN TEORI}

\subsection{Definisi Sistem}

Definisi sistem (Norman, 2004) menyatakan bahwa suatu sistem dapat terdiri atas kegiatankegiatan yang berhubungan guna mencapai tujuantujuan perusahaan seperti pengendalian inventaris atau penjadwalan produksi.

Sedangkan menurut (prajudi, 2004) menyatakan bahwa suatu sistem terdiri atas objekobjek, atau unsur-unsur, atau komponen-komponen yang berkaitan atau berhubungan satu sama lainnya sedemikian rupa sehingga unsur-unsur tersebut merupakan satu kesatuan pemprosesan atau pengolahan yang tertentu.

\subsection{Basis Data Berorientasi Objek (Database)}

Menurut Connolly dan Begg (2005, p15), "Basis data adalah sebuah koleksi logical data yang saling terhubung satu sama lain dan gambaran dari data tersebut dirancang untuk menemukan kebutuhan informasi pada suatu organisasi atau perusahaan".

Konsep Objek Oriented Database (OODB) bermula dari Objek Oriented Programming (OOP) yang kemudian dikembangkan menjadi Objek Oriented Design (OOD) dan pada akhirnya menjadi Objek Oriented Analysis (OOA). Didalam konsep objek oriented database kita dapat melakkukan pemodelan data dari semua atributatribut khusus dari iap model dan dapat dinyatakan dalam Bahasa umum (natural).

OODB pada dasarnya merupakan konsep dari pemrograman berorientasi objek secara umum ditambah dengan database sebagai media penyimpanan datanya yang berbentuk class-class, sehingga dalam hal ini masih berhubungan erat dengan Diagram ER (Entity Relational Diagram), walau sudah mengalami perubahan bentuk dalam memodelkan objek-objeknya. OODB masih menerapkan konsep dari Relational Database Manajemen Sistem (RDBMS). Mekanisme penyimpanan obje-objek dalam RDBMS ini Sering dikenal dengan istilah ORDBMS (Objek Relational Database Management System).

\subsection{Metode Waterfall}

Menurut (Rosa, 2011) model SDLC air terjun (waterfall) sering juga disebut model sekuensial liner atau alur hidup klasik. Model air terjun menyediakan pendekatan alur hidup perangkat lunak secara sekuensial atau terurut didalam dari analis, desain, pengodean, pengujian dan tahapan pendukung. 


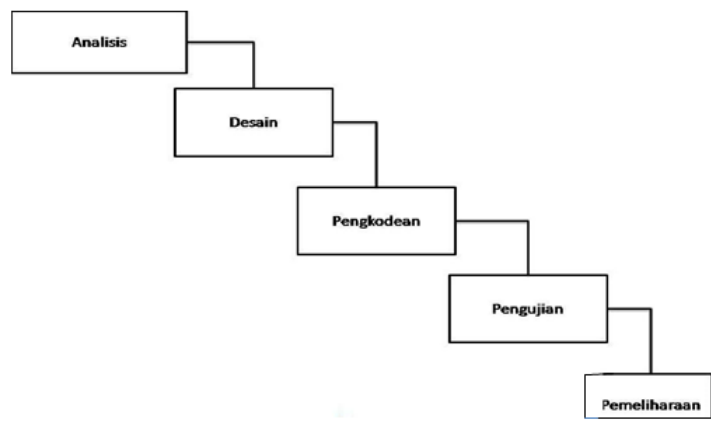

Gambar 1 Model Waterfall (Rosa a.sm.Shalahuddin:2011)

1. Analisa kebutuhan perangkat lunak Proses pengumpulan kebutuhan dilakukan secara intensif untuk menspesifikasikan kebutuhan perangkat lunak agar dapat dipahami perangkat lunak seperti apa yang dibutuhkan oleh user. Spesifikasi kebutuhan perangkat lunak pada tahap ini perlu untuk didokumentasikan

2. Desain

Desain perangkat lunak adalah proses multi langkah yang focus pada desain pembuatan program perangkat lunak termasuk struktur data, arsitektur perangkat lunak, representasi antarmukam, dan prosedur pengodean. Tahap ini mentranslasi kebutuhan perangkat lunak dari tahap analis kebutuhan ke representasi desain agar dapat diimplementasikan menjadi program pada tahap selanjutnya. Desain perangkat lunak yang dihasilkan pada tahap ini juga perlu didokumentasikan.

3. Pembuatan Kode Program

Desain harus ditranslasikan ke dalam program perangkat lunak. Hasil dari tahapan ini adalah program komputer sesuai dengan desain yang telah dibuat pada tahapan desain.

4. Pengujian

Pengujian fokus pada perangkat lunak secara dari segi lojik dan fungsional dan memastikan bahwa semua bagian sudah diuji. Hal ini dilakukan untuk meminimalisir kesalahan (error) dan memastikan keluaran yang dihasilkan sesuai dengan yang diinginkan.

5. Pendukung (support) atau pemeliharaan (maintenance)

Tidak menutup kemungkinan sebuah perangkat lunak mengalami perubahan ketika sudah dikirimkan ke user. Perubahan bias terjadi karena adanya kesalahan yang muncul dan tidak terdeteksi saat pengujian atau perangkat lunak harus beradaptasi dengan lingkungan baru. Tahap pendukung atau pemeliharaan dapat mengurangi proses pengembangan mulai dari analis spesifikasi untuk perubahan perangkat lunak yang sudah ada, tapi tidak untuk membuat perangkat lunak baru.

2.4 UML

UML singkatan dari Unitified Modeling
Language yang berarti bahas pemodelan standar. (Prabowo, 2011), mengatakan sebagai bahasa, berarti UML memiliki sintaks dan semantic. Ketika kita membuat model menggunakan konsep UML ada aturan-aturan yang harus diikuti. Bagaimana elemen pada model-model yang kita buat berhubungan satu dengan yang lainnya harus mengikuti standar yang ada. UML bukan hanya sekedar diagram, tetapi juga menceritakan konteksnya. Ketika pelanggan memesan suatu sistem, bagaimana transaksinya? Bagaimana sistem mengatasi error yang terjadi ? Bagaimana keamanan terhadap sistem yang kita buat? Dan sebagainya dapat dijawab dengan UML.

UML diaplikasikan untuk maksud tertentu, biasanya antara lain untuk :

1. Merancang perangkat lunak

2. Sarana komunikasi antara perangkat lunak dengan proses bisnis.

3. Menjabarkan sistem secara rinci untuk analisa dan mencari apa yang diperlukan sistem

4. Mendokumentasi sistem yang ada, prosesproses dan organisasinya.

\subsection{Diagram-Diagram Uml}

Menurut (Rosa, 2011), UML merupakan bahasa visual untuk pemodelan dan komunikasi mengenai sebuah sistem dengan menggunakan diagram dan teks-teks pendukung.

\subsubsection{Use Case Diagram}

Use case diagram atau diagram use case merupakan pemodelan untuk kelakuan (behavior) sistem informasi yang akan dibuat. Use case mendeskripsikan sebuah interaksi antara satu atau lebih aktor dengan sistem informasi yang akan dibuat. Secara kasar, use case digunakan untuk mengetahui fungsi apa saja yang ada didalam sebuah sistem informasi dan siapa.

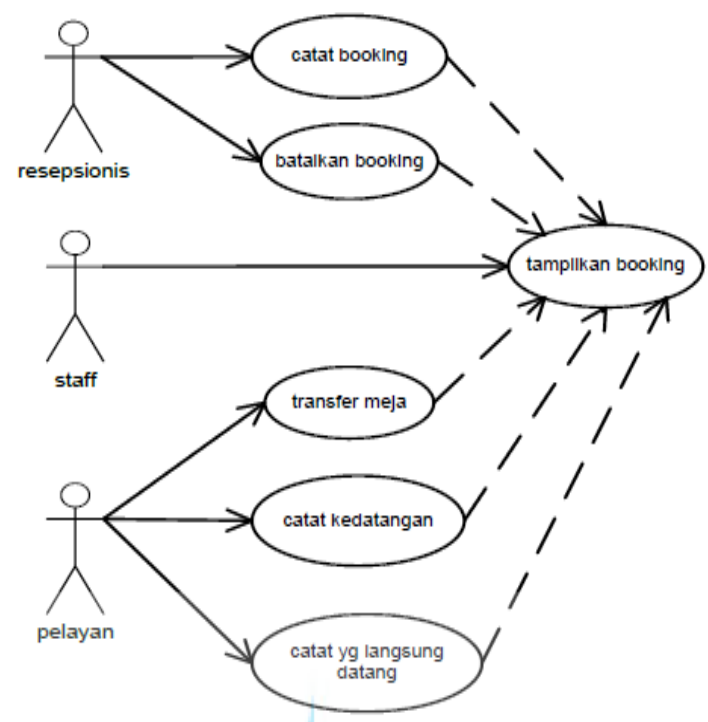

Gambar 2 Contoh Use Case Diagram (Munawar:2005:69)

\subsubsection{Activity Diagram}

Definisi diagram aktifitas atau activity diagram menurut Rosa, Salahudin (2011:134) "adalah 
diagram yang menggambarkan workflow (aliran kerja) atau aktfitas dari sebuah sistem atau proses bisinis". Yang perlu diperhatikan disini adalah bahwa diagram aktivitas menggambarkan aktifitas sistem bukan yang dilakukan actor, jadi aktifitas yang dapat dilakukan oleh sistem.

Activity diagram menggambarkan aliran fungsional sistem, pada tahap pemodelan bisnis, diagram aktivitas dapat digunakan untuk menunjukan aliran kerja bisnis dan untuk menggambarkan aliran kejadian dalam use case. Diagram aktivitas juga banyak digunakan untuk mendefiniskan hal-hal berikut:

1. Rancangan proses bisnis dimana setiap urutan aktivitas yang digambarkan merupakan proses bisnis sistem yang didefinisikan.

2. Urutan atau pengelompokan tampilan dari sistem dimana setiap aktivitas dianggap memiliki sebuah rancangan antar muka tampilan.
3. Rancangan pengujian dimana aktivitas dianggap memerlukan sebuah pengujian yang perlu didefinisikan kasus ujinya.

\subsubsection{Sequence Diagram}

Diagram sekuen menggambarkan kelakuan objek pada use case dengan mendeskripsikan waktu hidup objek dan massage yang dikirimkan dan diterima antar objek. Oleh karena itu untuk menggambarkan diagram skuen maka harus diketahui objek-objek yang terlibat dalam sebuah use case beserta metode-metode yang dimiliki kelas yang di instansikan menjadi objek itu.Banyak diagram skuen yang harus digambarkan adalah sebanyak pendefinisian use case yang memiliki proses sendiri atau yang penting semua use case yang telah didefinisikan interaksi jalannya pesan sudah cikapu pada diagram skuen sehingga semakin banyak use case yang didefinisikan maka diagram sekuen yang harus dibuat juga semakin banyak.

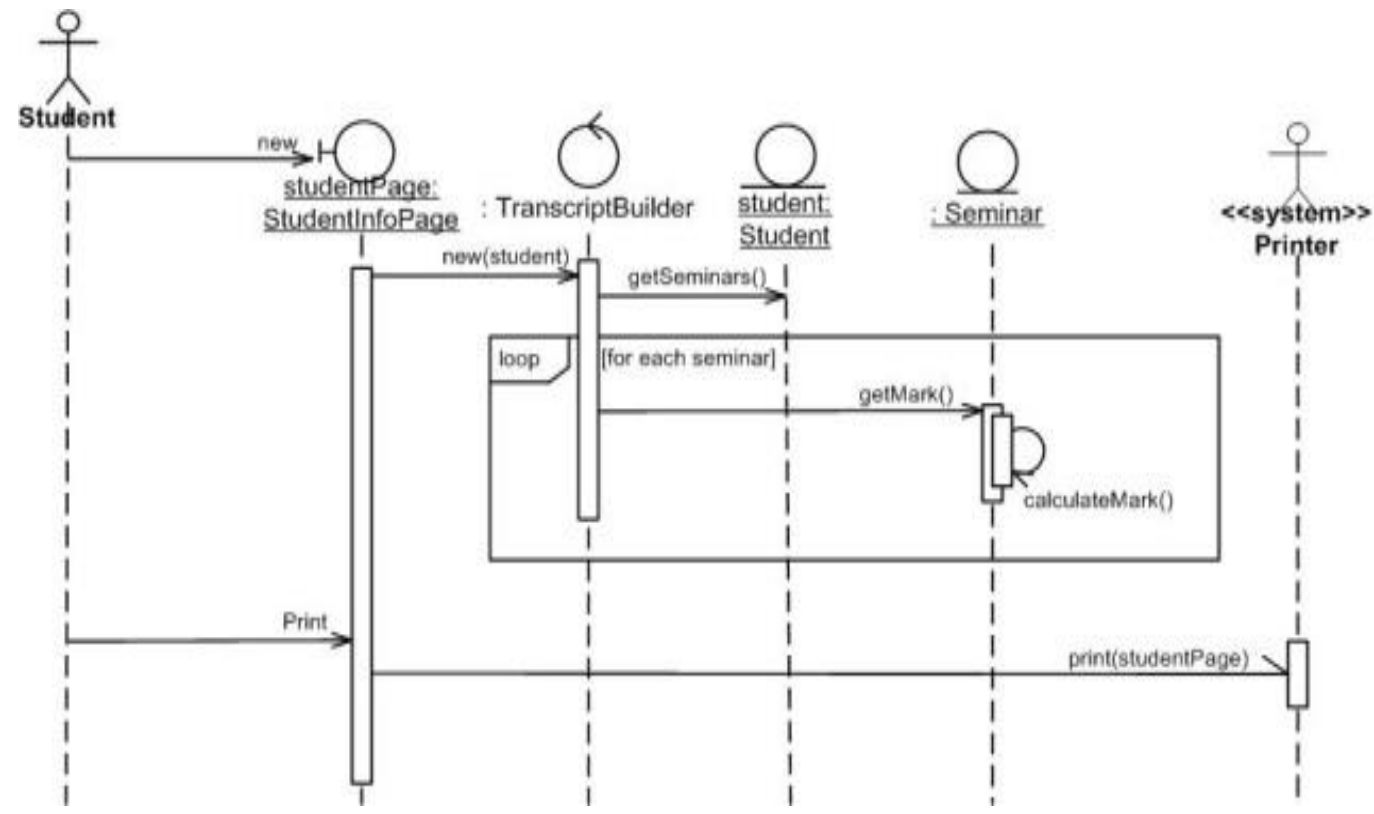

Gambar 3 Contoh Sequence Diagram (Rosa a.s-m.Shalahuddin:2011:138)

\subsection{PHP 5 (Hypertext Preprocessor)}

PHP versi 5 muncul untuk menangani kelemahan-kelmahan yang terdapat pada versi sebelumnya sampai buku ini ditulis, sudah dikeluarkan PHP 5.0.1 yang juga disertakan dalam CD. PHP versi 5 dapat membuat file swf dan applet java. Secara resmi, PHP versi 5 diluncurkan pada Desember 2003. Fokus utamanya adlah mengoptimalkan penggunaan PHP untuk OOP(Objeck Orientid Program).

PHP menurut (M. Rudyanti, 2011), PHP (Hypertext Prepocessor) adalah bahasa server-side scriping yang menyatu dengan HTML untuk membuat halaman web yang dinamis. Karena PHP merupakan server-side scriping maka sintaks dan perintah-perintah PHP akan dieksekusi di sarver kemudian hasilnya dikirimkan ke browser dalam format HTML. Dengan demikian kode program yang ditulis dalam PHP tidak akan terlihat oleh user sehingga keamanan halaman web yang dinamis, yaitu halaman web yang dapat membentuk suatu tampilan berdasarkan permintaan terkini, seperti penampilan isi basis data ke halaman web.

\subsection{Android}

Android adalah sebuah kumpulan perangkat lunak untuk perangkat mobile yang mencakup sistem operasi, middleware dan aplikasi utama mobile. Telepon seluler menggunakan berbagai macam sistem operasi seperti Symbian OS $\AA$, Microsoft's Windows Mobile $\AA$, Mobile Linux $\AA$, iPhone OS $\AA$ (berdasarkan Mac OS X), Moblin $\AA$ (dari Intel), dan berbagai macam sistem operasi lainnya. API yang tersedia untuk mengembangkan 
aplikasi mobile terbatas dan oleh karena itulah Google mulai mengembangkan dirinya. Platform Android menjanjikan keterbukaan, kemudahan untuk menjangkau, source code yang terbuka, dan pengembangan framework yang high end.

\subsection{Haversine Formula}

Haversine formula merupakan sebuah persamaan yang penting dalam navigasi, dimana formula ini memberikan jarak di antara dua titik pada lingkaran bola dari setiap garis bujur (longitude) dan garis lintang (latitude). Ini adalah kasus khusus dari sebuah formula yang lebih umum dalam trigonometri lingkaran bola, law of haversines, haversine formula menghubungkan sisi dan sudut dari sebuah segitiga bola.

Haversine formula nantinya akan digunakan dalam perhitungan jarak antara dua titik. Dalam hal ini adalah titik posisi user dan titik posisi tujuan, sehingga dapat menjadi kunci utama dalam perbandingan jarak pada penentuan jarak terdekat.

\section{ANALISIS DAN PERANCANGAN}

\subsection{Analisa Sistem Berjalan}

Sebelum dilakukan perancangan dan pembuatan aplikasi pencarian ustadz/ustadzah in perlu dilakukan analisis terhadap permasalahan yang ada berkaitan dengan tujuan perancangan yang ditentukan sejak awal. Seseorang yang ingin mencari seorang ustadz/ustadzah haruslah tahu rumah atau contact person ustadz/ustadzah yang di inginkan seseorang tersebut, jika tidak seseorang yang ingin mencari ustadz/ustadzah haruslah bertanya kepada narasumber yang tahu dengan jelas alamat rumah ataupun contact person sang ustadz/ustadzah. Ketika alamat rumah sang ustadz/ustadzah diketahui langsung saja seseorang tersebut datang ke alamat yang diberitahu narasumber. Ada salah satu kesulitan bagi seseorang yang tidak tahu arah jalan, arah menuju alamat rumah sang ustadz/ustadzah. Sehingga ada rasa jenuh dan malas untuk menuju rumah sang ustadz/ustadzah tersebut. Ada pula orang yang malu ingin bertanya ke beberapa narasumber hanya untuk mencari alamat sang ustadz/ustadzah disekitar rumahnya.

\subsection{Proses Untuk Mendapatkan Alamat Ustadz/Ustadzah}

Prosedur merupakan urutan dari langkahlangkah yang terjadi atau yang dilakukan dalam suatu sistem. Prosedur sistem yang sedang berjalan dikehidupan bermasyarakat dalam pencarian ustadz. Proses pertama yang dilakukan seseorang jika ingin mencari alamat ustadz/ustadzah secara manual dengan menemui salah satu narasumber yang sangat tahu jelas alamat atau contact person sang ustadz/ustadzah yang diinginkan. Jika narasumber tahu dan memberikan langsung alamat atau contact person sang ustadz/ustadzah, langsung saja seseorang tersebut menuju alamat yang diberikan dari narasumber. Ketika narasumber tidak mengetahui alamat atau contact person sang ustadz/ustadzah, seseorang tersebut langsung mencari narasumber lain yang diyakinkan tahu jelas alamat atau contact person sang ustadz/ustadzah.

\subsection{Analisa Sistem Usulan}

Untuk memberikan kemudahan dalam pencarian alamat rumah ustadz/ustadzah pada sistem yang akan dibuat, dirancang berbagai fasilitas yang dapat memudahkan masyarakat yang ingin mencari ustadz/ustadzah sekitar rumah atau pengguna aplikasi secara efisien. Aplikasi pencarian ustadz/ustadzah wilayah DKI Jakarta berbasis android ini dapat diakses oleh pemilih di mana saja dan kapan saja melalui handphone berbasis android. Aplikasi ini dapat membantu seseorang yang ingin mencari ustadz/ustadzah demi mengajarkan ilmu agama ataupun ceramah di acara-acara yang berunsurkan keagamaan. Masyarakat umum yang tidak mengetahui alamat atau contact person ustadz/ustadzah bisa mengetahuinya di aplikasi ini. Seseorang yang ingin mencari ustadz/ustadzah diwilayah sekitar rumahnya dapat menggunakan aplikasi ini, karena aplikasi ini dirancang dengan menggunakan sistem LBS (Location Based Service) yang beralgoritma Haversine Formula, yang gunanya mencari penelusuran terdekat. Dengan aplikasi ini masyarakat akan dimudahkan untuk mencari ustadz/ustadzah dimana saja dan kapan saja melalui handphone berbasis android. Dengan aplikasi ini pun masyarakat bisa diarahkan ketujuan atau ke alamat rumah Ustadz/Ustadzah menggunakan navigasi dengan rute terdekat. Sehingga ini dapat memudahkan sekali ke rumah Ustadz/Ustadzah yang diinginkan.

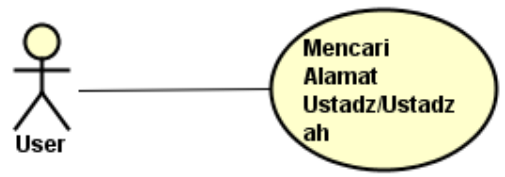

Gambar 4 Use Case Diagram Sistem Berjalan

\subsection{Activty Diagram}

\section{Activity Diagram Pencarian Ustadz/} Ustadzah

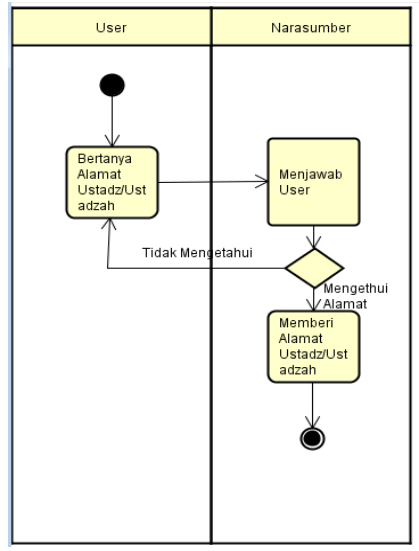

Gambar 5 Activity Diagram Pencarian Ustadz/Ustadzah 
2. Activity Diagram Login

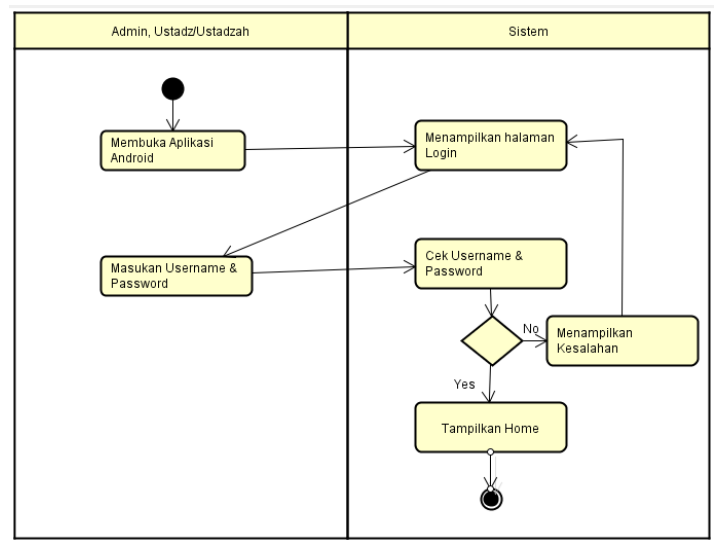

Gambar 6 Activity Diagram Login

Gambar diatas tampak activity diagram login dimana admin dan ustadz/ustadzah membuka aplikasi sehingga sistem menampilkan halaman login, ketika itu masukan username \& password yang sudah terdaftar, sistem akan mengecek jika benar username dan password maka sistem akan menampilkan tampilan home, jika username atau password salah sistem akan menampilkan kesalahan.

\section{Activity Diagram Mengelola Ustadz/ Ustadzah}

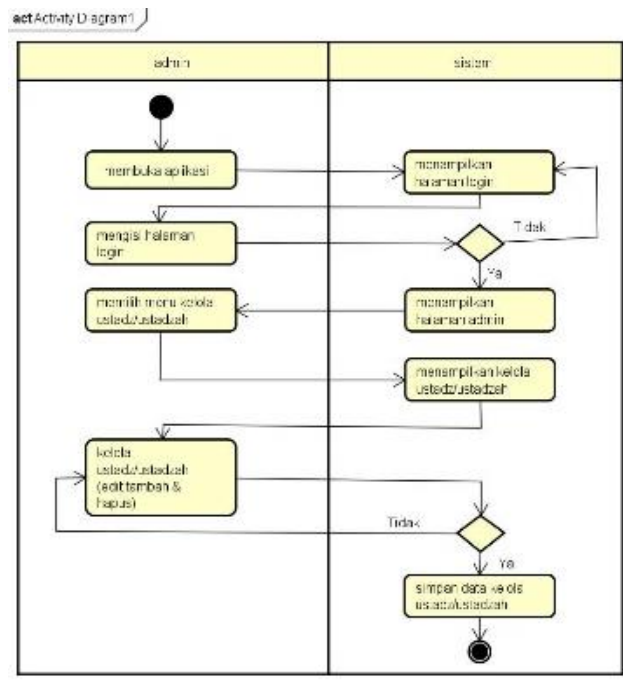

Gambar 7 Activity Diagram Mengelola Ustadz

3.6 Sequemce Diagram Usulan

Sequence Diaram Login

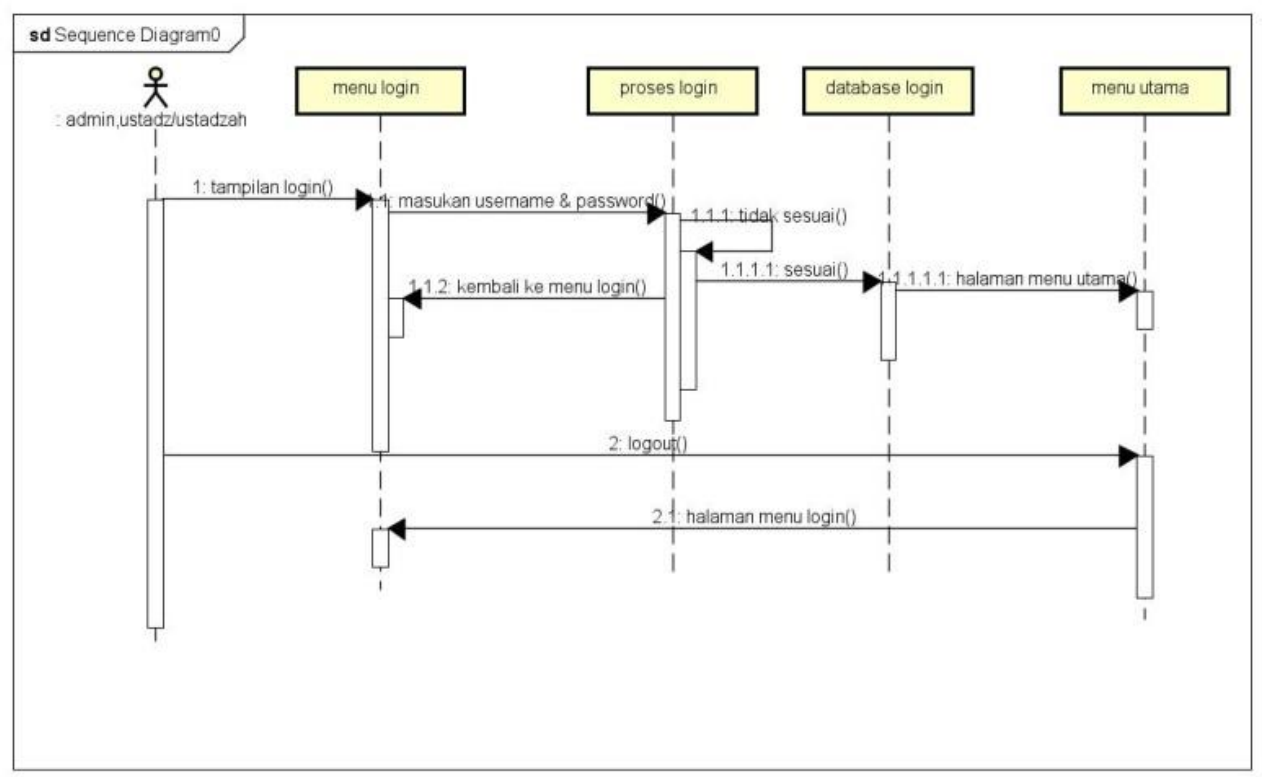

Gambar 8 Sequence Diagram Login

\subsection{Perancangan Tampilan}

\section{Rancangan Menu Utama}

Form Menu Utama

Berikut tampilan utama ketika membuka aplikasi, akan muncul gambar logo dan beberapa menu yang berisi pencarian ustadz/ustadzah, menu login (untuk admin, ustadz/ustadzah), menu registrasi ustadz (khusus ustadz/ustadzah), menu lupa password, menu tentang.

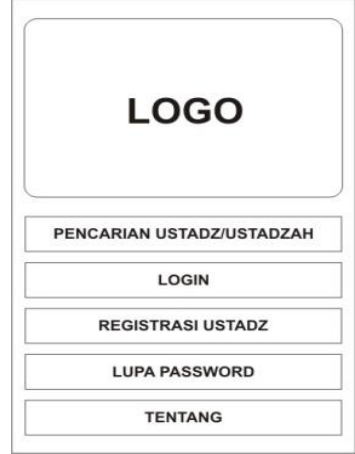

Gambar 9 Rancangan Tampilan Menu Utama 


\section{Rancangan Tampilan Login}

Menu Login

$\begin{array}{lllr}\text { Username : } & \text { Varchar(20). Disini admin \& } \\ & \text { ustadz/ustadzah } & \text { memasukan } \\ \text { Psername keform Login. } & \\ \text { Password } & \text { Varchar(12). } & \text { Disini } & \text { admin, } \\ & \text { ustadz/ustadzah disuruh untuk } \\ & \text { memasukan password milik admin \& } \\ & \text { ustadz/ustadzah untuk masuk } \\ & \text { kemenu kelola. }\end{array}$

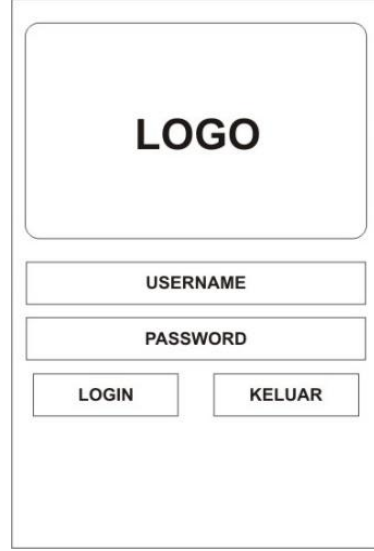

\section{Gambar 10}

Rancangan Tampilan Login

\section{Algoritma Pencarian Ustadz/Ustadzah}

\footnotetext{
DELIMITER \$ $\$$

- Functions
}

CREATE FUNCTION 'get_distance_between_geo_locations'( 'latl' FLOAT, 'longl' FLOAT, 'lat2' FLOAT, 'long2' FLOAT) RETURNS float DETERMINISTIC

BEGIN DECLARE distance FLOAT DEFAULT - 1 ;

DECLARE earthRadius FLOAT DEFAULT 6371.009;

DECLARE axis FLOAT;

IF ((latl is NOT NULL) AND (longl is NOT NULL) AND (lat2 is NOT NULL) AND (long2 IS NOT NULL))

THEN

SET axis $=(\operatorname{SIN}($ RADIANS $($ lat2-lat1) $/ 2) * \operatorname{SIN}($ RADIANS $($ lat2-lat1) $/ 2)$

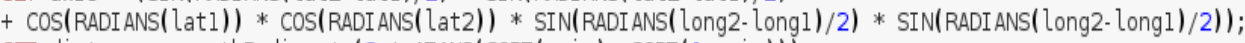

SET distance = earthRadius * $(2 * \operatorname{ATAN2}(\operatorname{SQRT}($ axis $), \operatorname{SQRT}(1$-axis $)))$;

END IF;

RETURN distance;

END\$\$

DELIMITER

Gambar 11 Code Algoritma Pencarian Ustadz/Ustadzah

\section{IMPLEMENTASI DAN UJI COBA}

Pada bab ini menerangkan tentang Implementasi Sistem yaitu merupakan pengaplikasian perangkat lunak dan perangkat keras serta database yang digunakan. Tahapan ini dilakukan setelah perancangan selesai dilakukan dan selanjutnya diimplementasi pada bahasa pemrograman, meliputi implementasi Aplikasi yang di buat, batasan implementasi, implementasi perangkat lunak, implementasi perangkat keras, implementasi antar muka, dan implementasi database.

\subsection{Implementasi}

Implementasi atau tahap penerapan ini adalah suatu bentuk kegiatan yang merupakan rangkaian lanjutan dari kegiatan perancangan perangkat lunak, implementasi ini dimaksudkan untuk mewujudkan hasil dari perancangan perangkat lunak. Hasil ini merupakan hasil dari kegiatan rangkaian implementasi perancangan perangkat lunak adalah proses aplikasi yang telah dibuat dan sudah dapat digunakan serta berfungsi dengan baik. Pada umumnya implementasi adalah proses penerapan rancangan program yang telah dibuat pada bab sebelumnya atau aplikasi dalam melaksanakan perancangan aplikasi pemrograman yang dibuat.

\subsection{Implementas Basis Data}

Tampilan Database Pencarian

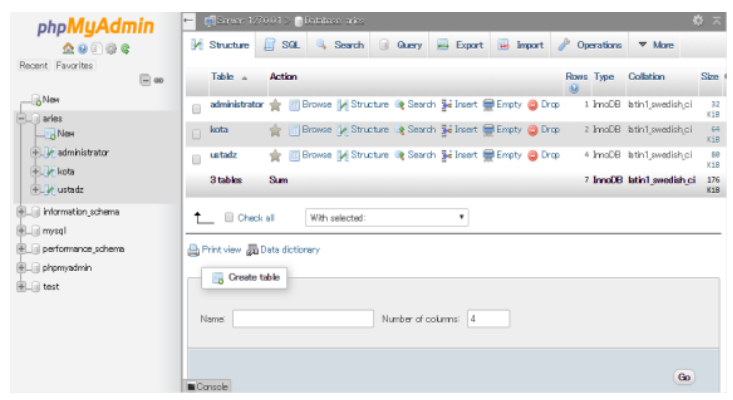

Gambar 12 Database Pencarian

Ini adalah tampilan database pencarian. Disini terdapat tabel administrator, kota, ustadz.

\subsection{Implementasi dan Pengujian Program}

Berikut ini adalah implementasi dan pengujian program sesuai dengan rancangan layar yang telah dibuat sebelumnya, anatara lain : 
1. Tampilan Login Admin \& Ustadz
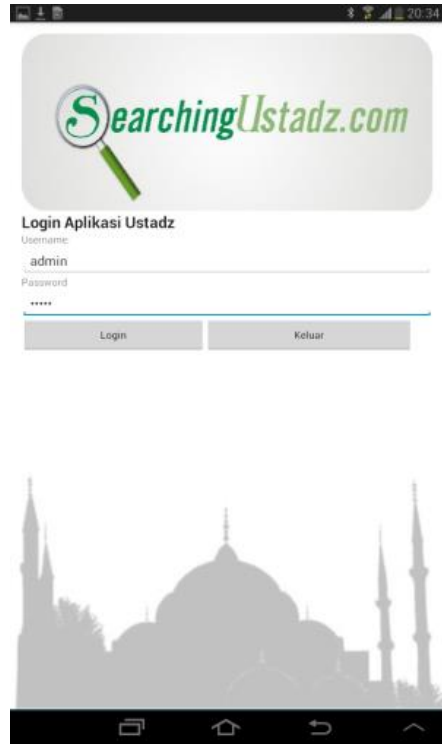

Gambar 13 Tampilan Login Admin

Ini adalah tampilan login admin sebelum memasuki halaman admin atau ustadz/ustadzah Disini terdapat username dan password, disini admin atau ustadz/ustadzah diminta memasukan username dan password agar dapat memasuki menu admin.

\section{Tampilan Menu Pencarian Ustadz/Ustadzah}

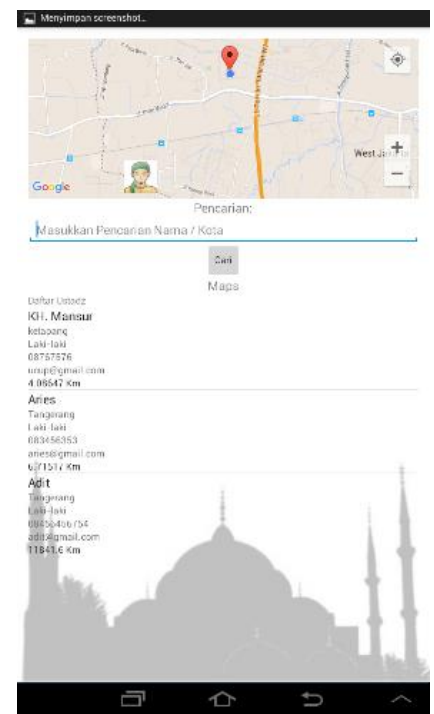

Gambar 14 Tampilan Menu Pencarian Ustadz

Ini adalah tampilan halaman pencarian ustadz/ustadzah, user bisa langsung mencari ustadz/ustadzah yang terdekat dari user, akan tertera nama ustadz/ustadzah yang terdekat dari user, tidak hanya yang terdekat, user pun bisa mencari ustadz/ustadzah berdasarkan nama atau kota, user hanya ketikan nama kota ataua nama ustadz/ustadzah kemudian klik cari, dengan otomatis sistem akan menampilkannya.

\section{Tampilan Menu Kelola Ustadz/Ustadzah}
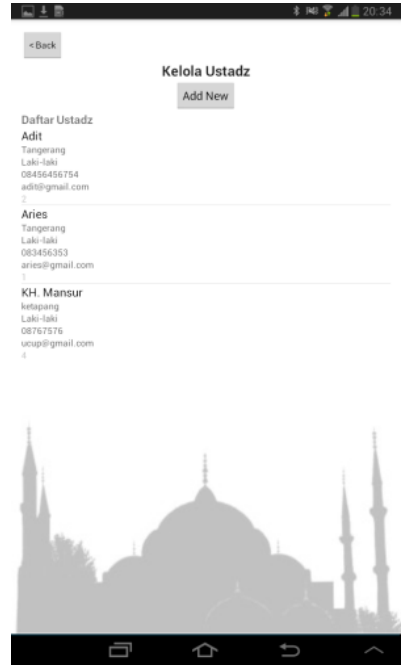

Gambar 15 Tampilan Menu Kelola Ustadz

Ini merupakan tampilan dari menu kelola ustadz/ustadzah. Disini admin dapat mengelola data ustadz/ustadzah seperti, menambahkan ustadz/ustadzah, mengubah data ustadz/ustadzah dan menghapus data ustadz/ustadzah.

\subsection{Metode Pengujian}

Metode pengujian dilakukan untuk memastikan apakah sistem yang akan dipakai sudah sesuai dengan yang diharapkan. Metode yang digunakan untuk pengujian ini adalah black box, yaitu melakukan pengujian degan memfokuskan pada fungsionality sistem tanpa mengetahui apa sesungguhnya yang terjadi dalam black end system.

\subsubsection{Prosedur Pengujian}

Pengujian yang digunakan adalah pengujian black box (black-box testing), black box testing terfokus pada apakah unit program memenuhi kebutuhan atau requirement yang disebutkan dalam spesifikasi. Pada black box testing cara pengujian hanya dilakukan dengan menjalankan atau mengeksekusi unit atau modul, kemudian diperhatikan apakah hasil dari unit atau modul itu sesuai dengan proses bisnis yang diinginkan.

Pengujuan dengan menggunakan metode black box testing dilakukan dengan cera memberikan sejumlah masukan pada program aplikasi yang kemudian diproses sesuai dengan kebutuhan fungsional nya untuk melihat apakah program aplikasi menghasilkan keluaran yang sesuai dengan kebutuhan fungsionalnya, makan program aplikasi yang dirancang berhasil tetapi bila output yang dihasilkan tidak sesuai dengan kebutuhan fungsionalnya, maka masih terdapat kesalahan pada program aplikasi itu.

Pengujian dilakukan dengan mencoba semua kemungkinan yang terjadi dan dilakukan secara berulang-ulang. Jika dalam pengujian ditemukan kesalahan, makan akan dilakukan pencarian dan perbaikan untuk memperbaiki kesalah yang terjadi. Jika telah selesai melakukan perbaikan makan 
akan dilakukan pengujian kembali. Pengujian dan perbaikan dilakukan secara terus menerus hingga diproleh hasil yang sesuai.

\subsubsection{Skenario Pengujian}

Skenario pengujian diperlukan untuk mengetahui apakah aplikasi yang dibuat dapat berfungsi dengan baik atau tidak. Skenario pengujian dilakukan dengan memilih dari setiap pilihan yang ada pada aplikasi e-voting berbasis web dan sms gateway ini, kemudian dilakukan pengujian dengan menekan tombol-tombol yang terdapat pada halaman form dari aplikasi ini apakah sudah sesuai dengan yang diharapkan.

Table 1 Rencana Pengujian Halaman Admin

\begin{tabular}{|c|c|c|c|c|c|}
\hline No & $\begin{array}{l}\text { Antar } \\
\text { Muka }\end{array}$ & Uji Coba & $\begin{array}{c}\text { Status } \\
\text { Aplikasi }\end{array}$ & $\begin{array}{l}\text { Skenario } \\
\text { Pengujian }\end{array}$ & $\begin{array}{l}\text { Hasil yang } \\
\text { diharapkan }\end{array}$ \\
\hline 1 & $\begin{array}{l}\text { Menu } \\
\text { Login }\end{array}$ & Proses Login & $\begin{array}{c}\text { Masukan } \\
\text { Username } \\
\text { dan } \\
\text { Password } \\
\end{array}$ & Input data & $\begin{array}{l}\text { Menu Utama } \\
\text { akan terbuka }\end{array}$ \\
\hline 2 & $\begin{array}{c}\text { Menu } \\
\text { Kelola } \\
\text { Ustadz } \\
\text { Ustadzah } \\
\end{array}$ & $\begin{array}{l}\text { Menguji inputan } \\
\text { dan simpan data } \\
\text { ustadz /ustadzah }\end{array}$ & $\begin{array}{c}\text { Laman } \\
\text { ustadz } \\
\text { ustadzah } \\
\text { sudah aktif } \\
\end{array}$ & $\begin{array}{c}\text { Input data } \\
\text { ustadz/ustadzah } \\
\text { lalu pilih tombol } \\
\text { simpan } \\
\end{array}$ & $\begin{array}{c}\text { Data } \\
\text { ustadz ustadzah } \\
\text { akan tersimpan ke } \\
\text { database } \\
\end{array}$ \\
\hline 3 & $\begin{array}{c}\text { Menu } \\
\text { Kelola } \\
\text { Kota }\end{array}$ & $\begin{array}{l}\text { Menguji inputan } \\
\text { dan simpan data } \\
\text { kota }\end{array}$ & $\begin{array}{l}\text { Laman Kota } \\
\text { sudah altif }\end{array}$ & $\begin{array}{l}\text { Input data kota lalu } \\
\text { pilih tombol } \\
\text { simpan }\end{array}$ & $\begin{array}{c}\text { Data kota akan } \\
\text { tersimpan ke } \\
\text { database }\end{array}$ \\
\hline 4 & $\begin{array}{l}\text { Menu } \\
\text { Logout }\end{array}$ & Proses link & $\begin{array}{c}\begin{array}{c}\text { Kembali ke } \\
\text { hamalan } \\
\text { awal }\end{array} \\
\end{array}$ & $\begin{array}{c}\text { Dapat kembali } \\
\text { kehalaman utama }\end{array}$ & $\begin{array}{c}\text { Terhubung } \\
\text { dengan halaman } \\
\text { link utama } \\
\end{array}$ \\
\hline
\end{tabular}

\subsubsection{Kasus dan Hasil Pengujian}

Berikut adalah beberapa hasil pengujian yang telah dilakukan, yaitu:

1. Pengujian Halaman Admin

Table 2 Pengujian Login Admin

\begin{tabular}{|c|c|c|c|}
\hline Data Masukan & Data Diharapkan & Pengamatan & Kesimpulan \\
\hline Data Admin & $\begin{array}{l}\text { Muncul halaman } \\
\text { utama }\end{array}$ & $\begin{array}{l}\text { Data masuk ke } \\
\text { halaman utama }\end{array}$ & $\begin{array}{l}\text { (v) Sesuai } \\
\text { () Tidak Sesuai }\end{array}$ \\
\hline \multicolumn{4}{|l|}{$\begin{array}{l}\text { Kasus dan Hasil } \\
\text { Uji (Data Salah) }\end{array}$} \\
\hline Data Masukan & Data Diharapkan & Pengamatan & Kesimpulan \\
\hline Data admin salah & $\begin{array}{l}\text { Menampilkan pesan } \\
\text { "Username dan } \\
\text { Password tidak } \\
\text { Valid" }\end{array}$ & $\begin{array}{l}\text { Menampilkan pesan } \\
\text { "Username dan } \\
\text { Password tidak } \\
\text { Valid" }\end{array}$ & $\begin{array}{l}\text { (v) Sesuai } \\
\text { () Tidak Sesuai }\end{array}$ \\
\hline $\begin{array}{l}\text { Data kosong atau } \\
\text { tidak diisi semua }\end{array}$ & $\begin{array}{l}\text { Menampillkan pesan } \\
\text { "Username dan } \\
\text { Password tidak } \\
\text { Valid" }\end{array}$ & $\begin{array}{l}\text { Menampilkan pesan } \\
\text { "Username dan } \\
\text { Password tidak } \\
\text { Valid" }\end{array}$ & $\begin{array}{l}\text { (v) Sesuai } \\
\text { () Tidak Sesuai }\end{array}$ \\
\hline
\end{tabular}

\section{Pengujian Kelola Data Calon Pemimpin}

Table 3 Pengujian Mengelola Data Ustadz Kasus dan Hasil Uji (Data Normal)

\begin{tabular}{|c|c|c|c|}
\hline Data Masukan & Data Diharapkan & Pengamatan & Kesimpulan \\
\hline $\begin{array}{l}\text { Klik link menu } \\
\text { kelola Ustadz/ } \\
\text { Ustadzah }\end{array}$ & $\begin{array}{l}\text { Menampilkan } \\
\text { tampilan form menu } \\
\text { ustadz/ustadzah }\end{array}$ & $\begin{array}{l}\text { Menampilkan } \\
\text { tampilan form } \\
\text { ustadz/ ustadzah }\end{array}$ & $\begin{array}{l}\text { (v) Sesuai } \\
\text { () Tidak Sesuai }\end{array}$ \\
\hline $\begin{array}{l}\text { klik tombol Add } \\
\text { New }\end{array}$ & $\begin{array}{l}\text { Data ustadz ustadzah } \\
\text { ditambah }\end{array}$ & $\begin{array}{l}\text { Data ustadz/ustadzah } \\
\text { ditambah }\end{array}$ & $\begin{array}{l}\text { (v) Sesuai } \\
\text { () Tidak Sesuai }\end{array}$ \\
\hline Klik tombol ubah & $\begin{array}{c}\text { Data ustadz/ustadzah } \\
\text { diubah }\end{array}$ & $\begin{array}{c}\text { Data ustadz/ustadzah } \\
\text { diubah }\end{array}$ & $\begin{array}{l}\text { (v) Sesuai } \\
\text { () Tidak Sesuai }\end{array}$ \\
\hline Klik tombol hapus & $\begin{array}{c}\text { Data Secara otomatis } \\
\text { dihapus }\end{array}$ & $\begin{array}{c}\text { Data Secara otomatis } \\
\text { dihapus }\end{array}$ & $\begin{array}{l}\text { (v) Sesuai } \\
\text { () Tidak Sesuai }\end{array}$ \\
\hline \multicolumn{4}{|l|}{$\begin{array}{l}\text { Kasus dan Hasil } \\
\text { Uji (Data Salah) }\end{array}$} \\
\hline Data Masukan & Data Diharapkan & Pengamatan & Kesimpulan \\
\hline $\begin{array}{c}\text { Data kosong atau } \\
\text { tidak diisi }\end{array}$ & $\begin{array}{c}\text { Menampilkan } \\
\text { pemebritahuan }\end{array}$ & $\begin{array}{l}\text { Menampilkan } \\
\text { pemberitahuan }\end{array}$ & $\begin{array}{l}\text { (v) Sesuai } \\
\text { () Tidak Sesuai }\end{array}$ \\
\hline
\end{tabular}

3. Pengujian Hail Voting
Table 4 Pengujian Pencarian Ustadz/Ustadzah Kasus dan Hasil Uji (Data Normal)

\begin{tabular}{|c|c|c|c|}
\hline Data Masukan & Data Diharapkan & Pengamatan & Kesimpulan \\
\hline Klik Menu & Menampilkan & Menampilkan & (v) Sesuai \\
Pencarian Ustadz/ & tampilan menu & tampilan menu & () Tidak Sesuai \\
Ustadzah & pencarian ustadz & pencarian ustadz/ & \\
& ustadzah & ustadzah & \\
\hline
\end{tabular}

4. Pengujian Logout Admin

Table 5 Pengujian Logout Admin Kasus dan Hasil Uji (Data Normal)

\begin{tabular}{|c|c|c|c|}
\hline Data Masukan & Data Diharapkan & Pengamatan & Kesimpulan \\
\hline Klik menu Logout & $\begin{array}{c}\text { Menampilkan } \\
\text { tampilan logout }\end{array}$ & $\begin{array}{c}\text { Menampilkan } \\
\text { tampilan logout }\end{array}$ & $\begin{array}{c}\text { ( }) \text { Sesuai } \\
\text { () Tidak Sesuai }\end{array}$ \\
\hline
\end{tabular}

\subsection{Analisa Hasil Pengujian}

Setelah dilakukan pengujian secara menyeluruh. Maka dapat disimpulkan bahwa pengujian telah menunjukkan hasil keluaran (Output) dan proses yang sesuai dengan rancangan aplikasi program ini. Dan hasil dari pengujian ini dapat dikatakan bahwa program ini dapat berfungsi dengan baik dan benar, karena telah dibuktikan dari hasil skenario pengujian. Hasil pengujian yang diperoleh dapat dianalisis sebagai berikut:

1. Halaman login, yang mengontrol aktifitas sub menu / link-link dalam sistem.

2. Halaman utama yang menghubungkan antar interface yang terdapat dalam menu berjalan dengan baik.

3. Menu form yang tersedia, hasil inputannya berhasil tersimpan kedalam database dengan tepat.

4. Menu Master, dan Laporan. Setiap tombol menu yang terdapat dimenu tersebut dapat berjalan sesuai perancangan sistem tersebut.

5. Hasil keluaran atau output dapat tercetak sesuai perancangan sistem yang diinginkan

\section{KESIMPULAN DAN SARAN}

\subsection{Kesimpulan}

Berdasarkan uraian-uraian yang telah dipaparkan pada bab-bab sebelumya, maka dapat menarik kesimpulan mengenai solusi yang tepat untuk mengatasi permasalahan adalah sebagai berikut:

1. Aplikasi Pencarian Ustadz ini ini telah dibuat sesuai dengan rancangan.

2. Aplikasi Pencarian Ustadz ini telah diuji menggunakan metode blackbox dan hasilnya sesuai dengan fungsi-fungsi yang dijalankan.

\subsection{Saran}

Dalam rancangan sistem yang diusulkan, diharapkan dapat bermanfaat dengan baik demi kemajuan dan perkembangan teknologi. Ada beberapa hal yang perlu diperhatikan dalam pelaksanaanya agar sistem dapat berjalan dengan baik.Saran yang bisa disampaikan : 
1. Diharapkan aplikasi ini dapat mengakses sampai luar wilayah DKI Jakarta bahkan bisa keseluruh dunia.

2. Diharapkan aplikasi ini dapat berkembang, tidak hanya mencari alamat rumah ustadz/ustadzah tetapi langsung mencari keberadaan ustadz/ustadzahnya.

3. Perlu diadakannya sosialisai terlebih dahulu baik dari pihak ustadz/ustadzah atau masyarakat.

4. Diharapkan aplikasi ini dapat dipublikasikan ke internet sehingga dapat diakses secara online oleh masyarakat.

\section{DAFTAR PUSTAKA}

[1] Azhari, R, 2005. Android, Makalah Fakultas Ilmu Komputer. USU. Medan

[2] Bell D, UML basics: An introduction to the Unified Modeling Language, IBM Developer Works,

http://www.ibm.com/developerworks/rational/li brary/769.html, (2003) June 15.

[3] Connolly, Thomas M., Carolyn E. Begg. (2005). Database Systems : A practical approach to design, implamentation, and management, fourth edition. USA : Pearson EducationLimited.

[4] M. Rudyanti Arief, 2004. Pemograman Web Dinamis Menggunakan PHP dan MySQL. Yogyakarta. Penerbit: Andi.
[5] Munawar. 2005. Pemodelan Visual dengan UML. Yogyakarta: Graha IImu

[6] Norman L, Enger, 2004. Analisa Sistem Informasi. Yogyakarta. Penerbit: Andi.

[7] Ohnemus, K. R. (1997, October 19-22). Web style guides: Who, what, where. In Proceedings of the 15th Annual International Conference on Computer Documentation, Salt Lake City, UT (pp. 189-197). ACM Publishing.

[8] Prabowo Pudjo Widodo, Herlawati, 2011. Menggunakan UML. Bandung. Penerbit: Informatika Bandung.

[9] Petrie, H., \& Kheir, O. (2007, April 28-May 3). The relationship between accessibility and usability of Web sites. In Proceedings of the SIGCHI Conference on Human Factors in Computing Systems (CHI 2007), San Jose, CA (pp. 397-406). ACM Publishing.

[10] Ponniah P, "Database Design and Development: An Essential Guide for IT Professionals", ISBN 0-471-21877-4 Copyright (C) 2003 by John Wiley and Sons, Inc., (2003).

[11] Rosa A.S-M Salahudin, 2011. Modul Pembelajaran Rekayasa Perangkat Lunak (Terstruktur Dan Berorientasi Objek). Bandung Penerbit: Modula. 